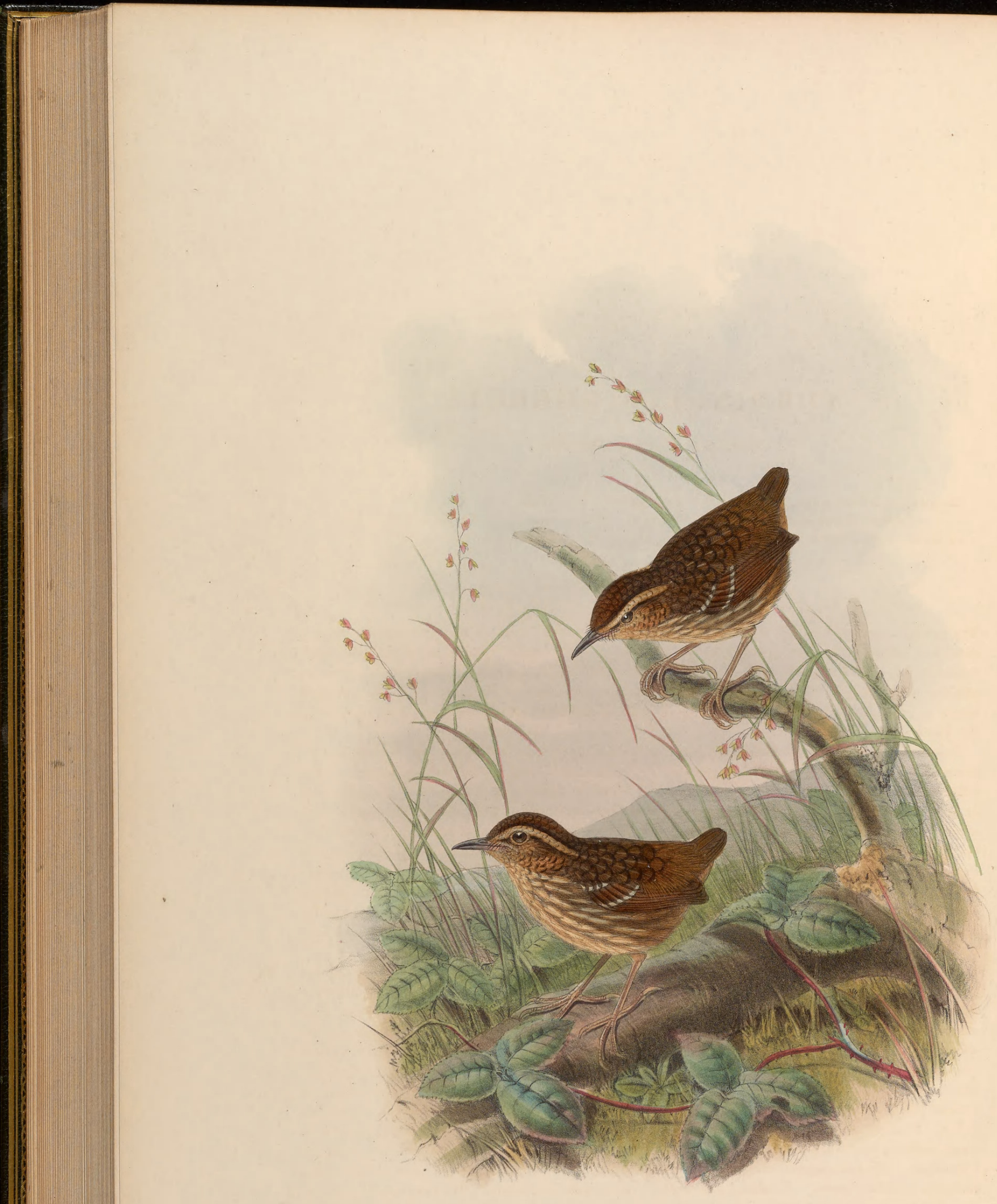

TURDINULUS ROBERTII. 


\title{
TURDINULUS ROBERTI.
}

\author{
Robert's Pygmy Babbler.
}

Pnoepyga, sp., Godwin-Austen, Journ. As. Soc. Beng. xxxix. p. 101 (1870). roberti, Godwin-Austen \& Walden, Ibis, 1875, p. 252.- Hume, Stray Feathers, 1876, p. 218

Turdinulus roberti, Hume \& Davison, Stray Feathers, 1878, p. 234.-Hume, op. cit. 1879, p. 93.

THE general aspect of this bird is so like that of a Pnoepyga that I am not surprised that its original describers placed it in that genus; but its plumage is quite unlike that of a Wren, and much resembles that of a Turdinus in colour. Mr. Hume has therefore, in my opinion, correctly indicated the affinities of the bird in his name Turdinulus; and I find, on examining the structure of the specimen before me, that it is a true Timeliine bird, with easily distinguishable rictal bristles. I at once adopt Mr. Hume's generic name for it.

The original specimens were obtained at Chakha in the Munipur hills, and at Asalu, by Mr. William Robert. It was observed also on Mooleyit in Tenasserim by Mr. Davison, at a height of 5500 feet and upwards. The following note on the habits of the birds is from the pen of the last-named naturalist :- "Generally seen in pairs, occasionally three or four together, hopping about on the ground or about the stems of the undergrowth only in the densest portions of the forest, and not preferentially near water. When alarmed, like $\boldsymbol{T}$. brevicaudatus, they all raise a note of alarm—' chick-chick, chick ; chick-chick, chick, chick,'一which they continually and unceasingly utter, until either you have passed on or they think they have got out of sight and danger. They are not shy, and do not fly unless very closely pressed, and then only for a short distance. As a rule, when disturbed, they leave the ground and thread their way with great rapidity amongst the stems of the brushwood, clinging sideways to these as many birds do. They are entirely insectivorous."

The following is a copy of the description given by Colonel Godwin-Austen and Lord Tweeddale :"Above olive-brown, each feather pale-centred and fringed or tipped with dark brown. Lores albescent. Between the eyes and the rictus black. A well-defined streak extending from above the eye down each side of the head fulvous. Ear-coverts cinereous at base, brown towards the tips. Chin and throat pure white, each throat-feather being terminated by a small black triangular drop; as the tips of the feathers overlap, these drops form continuous black lines, the two principal ones descending from the angles of the under mandible. Cheeks ferruginous, each feather with a black terminal drop. Pectoral and abdominal feathers pale brown, with broad pure-white or fulvous-white centres. Under tail-coverts bright ferruginous yellow. Plumage on the rump loose, soft, and dense, completely concealing the short tail, and being of an almost uniform ferruginous brown colour. Wings, when closed, dark chocolate-brown, most intense on the secondaries. Most of wing-coverts distinctly tipped with almost pure white, so also the inner tertiary quills. Rectrices chocolate-brown. Mandibles dark brown. Legs pale horn-brown. Bill from nostril 37 inch, wing $2 \cdot 15$, tarsus $\cdot 75$, tail $1 \cdot 15$."

The Plate, which represents two birds of the natural size, is drawn from a specimen kindly lent me by Colonel Godwin-Austen. 


\section{$2 \mathrm{BHL}$ Biodiversity Heritage Library}

Gould, John. 1882. "Roberts's Pygmy Babbler, Turdinulus roberti [PI. 62]." The Birds of Asia 3(XXXIV), -. https://doi.org/10.5962/p.323492.

View This Item Online: https://www.biodiversitylibrary.org/item/118635

DOI: https://doi.org/10.5962/p.323492

Permalink: https://www.biodiversitylibrary.org/partpdf/323492

\section{Holding Institution}

Smithsonian Libraries

\section{Sponsored by}

Smithsonian Institution Libraries

\section{Copyright \& Reuse}

Copyright Status: Not in copyright

This document was created from content at the Biodiversity Heritage Library, the world's largest open access digital library for biodiversity literature and archives. Visit BHL at https://www.biodiversitylibrary.org. 